\title{
Importance Of Teachers' Competency Through Students' Perception In Relationships Between Parental Involvement And Motivation With Students' Achievement
}

\author{
Rosmaria Omara, Nor Aniza Ahmada*, Siti Aishah Hassana, Samsilah Roslan ${ }^{b}$ \\ ${ }^{a}$ Faculty of Educational Studies, Universiti Putra Malaysia, 43400 Serdang, Malaysia \\ ${ }^{b}$ Research Management Centre, Putra Science Park, Universiti Putra Malaysia, 43400 Serdang, Malaysia \\ *Corresponding author: nor_aniza@upm.edu.my
}

Article history: Received: 17 September 2017 Received in revised form: 24 March 2018 Accepted: 6 Jun 2018 Published online: 22 November 2018

\begin{abstract}
Teachers' competency is important for the process of student 'well development' in ensuring quality learning especially for students in vocational colleges. Teachers' competency will give positive effects on students' academic development and skills, and help teachers to improve their teaching techniques. Therefore, collaboration between vocational college management and parents shall be increased to achieve integrated quality education, efficient teachers and contributes to positive impacts on students' standard achievement. Sample of 430 students were randomly stratified and the data had been collected by using questionnaire. The collected data had been analysed through Structural Equation Modeling (SEM) by using AMOS 22.0. Result of analysis showed that the hypothesized model had fulfilled the fitness indexes criteria where RMSEA $=.062, \mathrm{CFI}=.954$, TLI $=.936$ and Chi square/ $\mathrm{df}=2.404$. Implication of this study is giving contribution on improvement of theoretical model for the relationship of teachers' competency, parental involvement, achievement motivation and students' achievement in the Malaysian education system.
\end{abstract}

Keywords: Teachers' competency, parental involvement, achievement motivation, students' standard achievement, vocational college students

\section{Abstrak}

Kompetensi guru dalam pendidikan penting bagi proses 'kemenjadian' pelajar dalam memastikan pembelajaran yang berkualiti khususnya untuk pelajar di kolej vokasional. Kompetensi guru akan memberikan kesan positif terhadap pembangunan akademik serta kemahiran pelajar, dan membantu guru memperbaiki teknik pengajaran mereka. Oleh itu, kolaborasi antara pengurusan kolej vokasional dan ibu bapa perlu dipertingkatkan bagi mencapai pendidikan berkualiti secara bersepadu, guru-guru yang cekap dan menyumbang kepada impak positif terhadap standard prestasi pelajar. Sebanyak 430 sampel pelajar telah diambil secara rawak berstrata dan data dikutip dengan menggunakan soal selidik. Data yang diperoleh telah dianalisis melalui Permodelan Persamaan Berstruktur (SEM) dengan menggunakan AMOS 22.0. Keputusan analisis menunjukkan model hipotesis telah memenuhi kriteria indeks kesepadanan yang mana RMSEA $=0.062, \mathrm{CFI}=0.954, \mathrm{TLI}=0.936$ dan Chisquare $/ \mathrm{df}=2.404$. Implikasi kajian ini adalah memberi sumbangan kepada penambaikan model teoritikal bagi hubungan antara kompetensi guru, pelibatan ibu bapa, motivasi pencapaian dan standard prestasi pelajar dalam sistem pendidikan Malaysia.

Kata kunci: Kompetensi guru, penglibatan ibu bapa, motivasi pencapaian, standard prestasi pelajar, pelajar kolej vokasional

(C) 2018 Penerbit UTM Press. All rights reserved

\subsection{INTRODUCTION}

The quality of teachers is decisive for the success of students. Through the transformation of technical and vocational education, the government has been rebranding some of the vocational schools to vocational colleges since year 2012. Thus, teachers with quality and competencies are needed as educator of the colleges. Previously, Higher Education Leadership Academy (AKEPT) 2011 has conducted a qualitative study about teaching in Malaysia. Over 125 observations of teachers' competency in 41 schools throughout Malaysia, only $12 \%$ of instruction in delivering the teaching has achieved high standard in which the teachers applied their pedagogical practices, while $38 \%$ achieved satisfactory standard and 50\% is unfavourable. From the observation of Danielson (2014), teachers became passive when they are depending on teacher-centred lecture method compared to student centred learning. They also more focused on student understanding compared to encourage students with other elements such as classroom environment and two way communication. These elements are important in teaching because they are part of effective teachers' competency. Furthermore, the quality of education and performance of students depends on teachers which reflected in the discharge of their duties (Alkharusi, Aldhafri, Alnabhani, \& Alkalbani, 2014). Teachers also have been known as important influence on students' achievement as they play crucial role in educational attainment, and ultimately responsible for translating educational policies and principles into actions based on practices during interaction with the students 
(Akiri, 2013). Both teaching and learning processes depend on the teacher, thus no wonder an effective teacher has been conceptualized as one who produces desired results in the course of his/her duty as a teacher.

\subsection{PROBLEM STATEMENT}

Teachers' competency has been discussed in many researches in order to improve-the quality of education. According to Charlotte (2014), the most important influence on student learning is the quality of teaching, yet most schools still cannot define what good teaching is. When there is no clear definition of good teaching, problem will arise because teachers do not know what and how to improve their practices in the classroom and this can harm the results of students' achievement. This study will identify five domains in teachers' competencies which are preparation, classroom environment, communication, teaching, and professional responsibility as a teacher. Findings from Siti Syahirah (2011) showed that teacher preparedness to accept the transformation of technical and vocational were crucial. Most of the teachers were not fully competence in their preparation when they started their lesson especially in skills. Good facility and enough equipment also important in aiding teacher's competency. Some of the vocational colleges did not had enough equipment's in the workshop (Nurazimah \& Yusri, 2013), and students needed to share the tools causing some of them lose in track and some depends on their selves to get practices either in colleges or at home (Siti Syahirah, 2011). This lacking situation will lead to ineffective teachers, bad teaching and may result on poor students' achievement. Passive students may ignore the task and fully rely on teachers' effort to help them in order to get better result. Apart from that, most of the challenging task for the teachers are to deliver teaching effectively and get close with the students (Danielson, 2012). Every session in the classroom and workshop will be held smoothly once the students are comfortable with their environment. Teachers have to communicate well by building students' trust and encouraging them through various activities in the classroom especially during group work. Great team work and good communication will lead to better result for the students (Beamish, Meadows, \& Davies, 2012) and give satisfaction for the teachers. Preparation, classroom environment, teaching and learning, ethics and profesional responsibility were the gap of this research. Since vocational colleges are still new and just started from 2012, teachers' competency do plays the important roles towards students' achievement.

\subsection{LITERATURE REVIEW}

Recently, the Ministry of Education of Malaysia (MOE) (2013) has strengthened the importance of relationships between performance and competence of the teachers to empower the quality of education. Teachers have been evaluated using new teacher evaluation instrument since 2014. The dimensions that have been measured are assessment of teaching and learning, professional activities outside the classroom and teacher's professional contribution to community.

Research conducted by the Programme for International Student Assessment (2014) found that the practices of good teacher competency has a direct relationship with the parental involvement and enable to help students to excel in their learning. Johnetta, Storey, and Zhang (2011) also stated that when teachers are considered as partners to the parents, it gives beneficial development to the students. Collaboration between teachers and parents not only builds significant positive relationship between them, but bring positive impacts on students academically and non-academically (Abd Razak, Zuwati \& Umi Kalsum, 2013; Beamish, Meadows \& Davies, 2012; CurrieRubin \& Smith, 2014; Reece, Staudt, \& Ogle, 2013). Since communication has become part of teacher competency, it is important for the teachers to improve their skills to gain parents support and trust towards school. Close communication between teachers, parents and students can bring positive impacts by motivating students to have better relationships and encouraging students to become more successful in their achievement. Through this transformation, the communication between teachers and parents will create a unique relationship where they can work together to produce something that is very useful for students and school achievement.

However, the trend of parental involvement is different between the primary and secondary school. Studies by Demircan \& Erden (2014) and Murray, McFarland-Piazza \& Harrison (2014) found that parents in pre-school more active than parents in secondary schools and colleges. Parents tend to less involve when the children move on to higher levels of schooling because the child has grow up (LloydSmith \& Baron, 2010) and can be independent, and the parents believe that they cannot facilitate the child as the subjects become more complicated (Trung Lam \& Ducreux, 2013). Communication is an important element to build good collaboration between teachers, parents and students (Murray et al., 2014; Zakharov, Carnoy \& Loyalka, 2014), but the benefits of this relationship will diminish as the parents become less involve at higher level and definitely affects the students' achievement (Hill \& Tyson, 2009).

\subsection{OBJECTIVE OF THE STUDY}

Aim of the study is to explore the relationship between teachers' competency, parental involvement, students' achievement motivation and students' achievement. While the second objective is to determine an indirect relationships between the variables.

\subsection{RESEARCH QUESTION}

Is there a significant relationship between teachers' competency and parental involvement, students' achievement motivation and students' achievement? 


\subsection{HYPOTHESES}

The alternative hypotheses of this study are as follows:

$\mathrm{H}_{1}$ : There is a significant relationship between the teachers' competency and parental involvement.

$\mathrm{H}_{2}$ : There is a significant relationship between teachers' competency and students' achievement.

$\mathrm{H}_{3}$ : There is a significant relationship between teachers' competency and students' achievement motivation.

$\mathrm{H}_{4}$ : There is a significant relationship between parental involvement and students' achievement motivation.

$\mathrm{H}_{5}$ : There is a significant relationship between parental involvement and students' achievement.

$\mathrm{H}_{6}$ : There is a significant relationship between achievements motivation and students' achievement.

\subsection{METHODOLOGY}

This research is a quantitative cross-sectional study. The data was collected by using questionnaires.

\subsection{Samples}

The samples of this study were 430 students from 13 vocational colleges all around Peninsular Malaysia including Sabah and Sarawak. Samples were chosen by random stratified sampling technique. The sample size was determined by using sampling method of Bartlett, Kotrlik, \& Higgins (2001) and Cochran (1977). A random stratified sampling technique is used to ensure the research samples are balanced with each layer of research population (Reeves, 1993).

\subsection{Research Instruments}

The instruments that were used in this study were as follows:

i. Teacher Competency (IKG) by Nor Aniza, Siti Aishah, Lay Nee, and Nor Hashim (2016) consists of 94 items in four domains; planning and preparation (11 items), classroom climate (28 items), teaching (39 items) and profesional responsibilities (20 items).

ii. Students Perception on Parental Involvement by Epstein (1992) consist of 35 items in six domains; parenting (5 items), communicating (7 items), volunteering (5 items), learning at home (10 items), decision making (4 items) and collaborating with community (4 items).

iii. Achievement Motivation by Vallerand (1992) consist of 24 items in three domains; intrinsic motivation (12 items) and extrinsic motivation (12 items)

\subsection{Pilot Study}

A pilot study was conducted at three different vocational colleges which involved 150 respondents. The Alpha Cronbach $(\alpha)$ value for each instrument showed a high reliability values; teaching practices $(\alpha=.975)$, students perception on parental involvement $(\alpha=.933)$ and achievement motivation $(\alpha=.914)$.

\subsection{Data Analysis Method}

The primary data was analyzed by AMOS version 22.0 through Structural Equation Modeling (SEM) to explore direct and indirect relationships between dependent variable and independent variables.

\subsection{FINDINGS}

Results of the assessment were used to test the hypotheses and to answer the questions of the study. In this structural part of the model the following paths were measured:

- Teachers' competency influences parental involvement

- Teachers' competency influences students' achievement

- Teachers' competency influences students' achievement motivation

- Parental involvement influences students' achievement motivation

- Parental involvement influences students' achievement

- Students' achievement motivation influences students' achievement

Output Model of Relationship between Teachers' Competency, Parental Involvement, Students' Achievement Motivation and Students' Achievement

These paths reflected the relationships among constructs according to the theoretical hypotheses depicted in sub topic 5.0 hypotheses testing. The full model showed that there were three latent variables which were teacher competency, parental involvement, students' 
achievement motivation and one manifest variable which was student's achievement (Figure 1). Meanwhile, there also 18 observed variables that act as indicator to the latent variables.

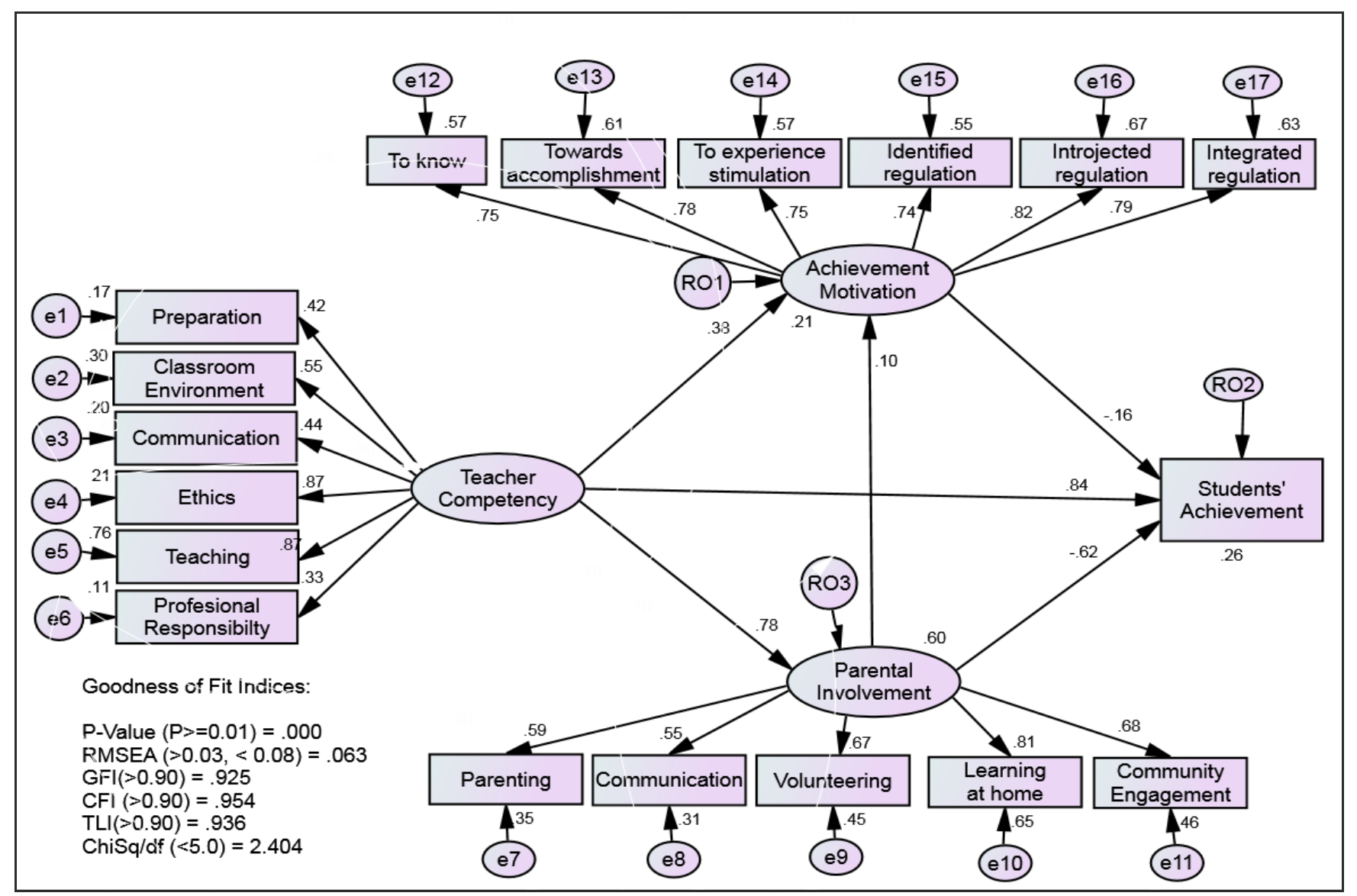

Figure 1 Output model of the relationship between teachers' competency, parental involvement, students' achievement motivation and students' achievement.

The output model of relationship between teachers' competency, parental involvement, students' achievement motivation and students' achievement resulted in a good fit, $p<.001$, RMSEA $=.063$, GFI=.925, CFI=.954, TLI=.936 and Chisq/df=2.404 (Table 1). All values had fulfilled the minimum requirement for the benchmark of fit indices. The $p<.001$, Root Mean Square of Error Approximation $($ RMSEA $)=.062$ which was <.0.08 indicated acceptable fit, Comparative Fit Index $(\mathrm{CFI})=.954$, Goodness of Fit Index $(\mathrm{GFI})=.925>.90$ and Tucker Lewis Index (TLI)=.945 were >.090 indicated good fit. All the loadings for the model of relationship between teachers' competency, parental involvement, students' achievement motivation and students' achievement among the uniqueness were fixed to 0.5, except for three sub domain in teachers' competency which were preparation, communication and profesional responsibility. Since the Fitness Indices were already met, the factor loading which have low factor loading no need to be deleted (Zainudin, 2015).

Table 1 The fit indices of hypothesized model

\begin{tabular}{lllllll}
\hline Model & P-value & RMSEA & GFI & CFI & TLI & Chisq/df \\
& & & & & & \\
\hline Hypothesize model & .000 & .063 & .925 & .954 & .936 & 2.404 \\
& & & & & & \\
\hline
\end{tabular}

\section{The Results of Hypothesized Testing}

Besides the goodness of fit indices, the causal path should be evaluated in terms of statistical significance and strength using standardized path coefficient that range between -1 and +1 . Based on $\alpha$ of 0.05 , the test statistic generated from the output should be greater than \pm 1.96 to indicate that the null hypothesis can be rejected. The rejection of the null hypothesis means that the structural coefficient is not zero (Bentler, 2010; Byrne, 2010; Hair, Hult, Ringle, \& Sarstedt, 2014). The standardized paths of a hypothesized model were computed and showed in Table 2. 
Table 2 Coefficient paths of a hypothesized model

\begin{tabular}{clc}
\hline Hypothesis & Causal Path & Standardized Path Coefficient \\
\hline HI & Teachers' Competency $\rightarrow$ Parental Involvement & 0.390 \\
H2 & Teachers' Competency $\rightarrow$ Students' Achievement & 0.001 \\
H3 & Teachers' Competency $\rightarrow$ Students' Achievement Motivation & 0.001 \\
H4 & Parental Involvement $\rightarrow$ Students' Achievement Motivation & 0.001 \\
H5 & Parental Involvement $\rightarrow$ Students' Achievement & 0.740 \\
H6 & Students' Achievement Motivation $\rightarrow$ Students' Achievement & 0.009 \\
\hline
\end{tabular}

In this hypothesized model, four of the paths were statistically significant. Comparing these results with the hypotheses, the standardized path coefficient of 0.390 seems to indicate that teachers' competency acquisition was positively associated with parental involvement (H1). Thus this hypothesis was supported. It showed that there is direct relationship between teachers' competency and parental involvement. The path coefficient of 0.001 suggested that teachers' competency was associated with students' achievement (H2), teachers' competency was positively associated with students' achievement motivation (H3), and parental involvement also had direct effect with students' achievement motivation (H4) and it was statistically significant. Thus all hypotheses were supported. Meanwhile, there is no direct relationship between parental involvement and students' achievement when the standardized path coefficient showed the result .740 (H5). Thus the hypothesis was not supported. The result also showed the path coefficient .009 for students' achievement motivation and students' achievement (H6), means that there is relationship between students' achievement motivation and students' achievement. Thus the hypothesis was supported.

\section{Indirect Relationships}

Indirect relationship between parental involvement, teachers' competency and students' achievement motivation had been analyzed by SEM (Table 3). It showed that teachers' competency have an indirect relationship with students' achievement through students' achievement motivation. This means that the teachers had influence greater motivation on students compared to their parents.

Table 3 Indirect relationships between variables

\begin{tabular}{llll}
\hline Path & Direct & Indirect & Total \\
\hline Teacher Competency $\rightarrow$ Achievement Motivation $\rightarrow$ Students' Achievement & .350 & .126 & .431 \\
\hline
\end{tabular}

In summary, the results of testing the research hypotheses indicated that one out of six recommended hypotheses was not supported. Thus, the five alternative hypotheses which were supported suggested that there were significant relationship between the studied variables.

\subsection{DISCUSSION}

Usually a hypothesized model will be tested with a linear equation system through Structural Equation Modeling (SEM). This method of study investigates the extent to which variations in one variable correspondence to variations in one or more variables based on correlation coefficient. Through SEM, the researcher will identify the goodness of fit in the hypothesized model and fulfill the minimum requirements which is $(p=.000, \mathrm{RMSEA}=.063, \mathrm{GFI}=.925 \mathrm{CFI}=.954, \mathrm{TLI}=.936$ and Chisq/df=2.404). There are several indicators of goodness of fit and most scholars recommend evaluating the models by observing more than one indicators (Bentler, 2010) and Hair et al., (2014). In terms of a model's goodness of fit, $p$ value indicates whether the model is significantly different than the null model. The null hypothesis is the hypothesized model in which the parameters are set up to indicate whether the path shall exist or not between the variables.

Results showed that the $p$ value for the hypothesized model was $p=.000$, which means that the observed model was not significantly different from what was expected. High $p$-value or a $p$-value larger than zero means that the null hypothesis is rejected and may leads to high probability it will be wrong in doing so (Gefen, Straub, \& Boudreau, 2000). While, p-value which is low or close to zero implies a "bad model" because the null hypothesis is rejected with low probability of being wrong in reaching that conclusion. Besides, RMSEA was measured by the discrepancy of the population. The results showed that RMSEA=.063 which means it was reasonably fit (Hair, Black, Babin, \& Anderson, 2010). Tucker Lewis Index (TLI) and Comparative Fit Index (CFI) compares a proposed model's fit to a nested baseline or null model. Both TLI=.936 and CFI=.954 in this research showed the values $>.90$, which were representing the acceptable fit. Then, Chisq/df was used to evaluate the goodness of fit. A small $\chi^{2}$ related to degree of freedom indicated good fit and Kline (2011) suggested that Chisq/df $<3.0$ as reasonably good indicator of model fit. The relationships between variables were determined once the model fitted. The results showed there was relationship between the variables.

Two relationships had been determined in this research which was direct and indirect relationships. From six paths, there were four paths had directly significant associated between the variables which were teachers' competency and students' achievement motivation $(\mathrm{TC} \rightarrow \mathrm{AM})$, students' achievement motivation and students' achievement $(\mathrm{AM} \rightarrow \mathrm{SA})$, parental involvement and students' achievement motivation $(\mathrm{PI} \rightarrow \mathrm{AM})$, and teacher competency was associating with students' achievement $(\mathrm{TC} \rightarrow \mathrm{SA})$. The direct relationships between parents and teachers through collaboration may influence the teachers in preparing class early in the morning, teaching in classroom, classroom environment and professional responsibilities towards students. As mentioned by Epstein et al., (2002), parents whom involved in their children's learning at home will encourage teachers to become more creative in their teaching, while teacher's practice in classroom will motivate the students to understand the lessons effectively. The students will realize their intention in study and encourage 
them to think the benefits of being in school for their future. Furrer \& Skinner (2003) stated that teacher's involvement was central to children's experience in the classroom, and teacher provision of both autonomy and support optimal structure predicted children's motivation throughout the year. This indicates that students-teacher relationship can improve the achievement among students. Motivational support provided by teachers also can effect students' motivation orientation and active class participation which leads to their excellence (Guvenc, 2015).

The findings also showed that there are no relationships between teachers' competency and parental involvement (TC $\rightarrow \mathrm{PI})$, and parental involvement and students' achievement $(\mathrm{PI} \rightarrow \mathrm{SA})$. Although parents have involved directly with their teachers and children's at schools and at home, this element does not influencing the achievement of vocational college's students in Malaysia. Noor Erma and Eu (2014) did research on factors influences student's achievement in technical and vocational school in Johor and got similar finding which is parental involvement had not contribute to student's achievement. This happened because some students who registered in vocational colleges were not really interested in technical fields, but they further their study there because of their parents' decision (Effendi, 2012). Alternatively, parents have to improve the relationship with their children in order to boost student's achievement. Parents not necessarily actively participate in school activities, but must have deep communication and good interaction with their children to increase the motivation and enhance better result in child's achievement, for both academic and technical fields.

Then, findings showed that achievement motivation has negative significant relationships towards students' achievement. This finding is supported by Onete and Calabar (2012) who found that achievement motivation did not has relationships with students' achievement in Nigeria and they suggested peer should be one of the factor that can strengthen the relationships. Mohd Effendi Ewan, Ahmad Zamri and Nordin (2015) also found that achievement motivation was negatively related with students' achievement among polytechnic students in Malaysia. Achievement goals have been viewed as more solid cognitive representations pointing individuals toward a specific end, and three of them are related to vocational students' achievement which performance-approach goal, a performance-avoidance goal, and a mastery goal. A performance-approach goal is focused on attaining competence relative to others, a performance-avoidance goal is focused on avoiding incompetence relative to others, and a mastery goal is focused on the development of competence itself and of task mastery. Achievement motives can be seen as direct predictors of achievement-relevant circumstances. Thus, achievement motives are said to have an indirect or distal influence, and achievement goals are said to have a direct or proximal influence on achievement-relevant outcomes (Elliot \& Church, 1997). Most of the respondents among the vocational colleges were less motivated people. Therefore, any influences wouldn't encourages them to get better results, instead of teachers as showing in the Figure $1, \mathrm{R}^{2}=26 \%$ for students' achievement were contributed by teacher competency. This result showed the importance of teacher competency towards students' achievement and teachers are an importance influence to help students to achieve their goals.

However, teacher competency showed an indirect relationship with achievement motivation through parental involvement. This is similar to the research finding by Nor Aniza et al., (2016) which parental engagement showed significant relationship with teacher competency and has indirect effect relationships between through achievement motivation. Unlike teachers, parents have an authority to support child education at home and provide their necessary which can motivate them to learn. But half of the students in vocational colleges are staying at the hostel, so they shall have attachment on the teachers as they are spending more times together. Though this finding showed that natural love between parents and children cannot be separated and their parents influence more compared to the teachers. Thus, collaboration between parents and teachers shall be improved in order to increase students' motivation and encourage them to perform better in class and workshop. Positive relationship between parents and teachers allows them to freely communicate about the children while sharing their goals and expectation (Hoover-Dempsey et al., 2001). This definitely will helps teachers to familiar with their students and can give better guidance to help them excel in study.

As conclusion, there are relationships between four variables that have been measured. PISA Assessment Report in Malaysia Blue Print Report 2013-2025 showed that Malaysia was the third bottom country in education achievement compare to Japan, Singapore and Finland. One of the government efforts is to increase levels of teaching competencies by building good relationship between teachers, parents and students to strengthen the inner factors which is the achievement motivation among students. This effort shall be utilized wisely as it can give a positive impact to transition Malaysia toward a knowledge based economy (Ramlee \& Abu, 2014). All of the domains will contribute to students' achievement in future undertaking.

\subsection{CONCLUSION}

This paper has provided a short discussion on the findings to answer six hypotheses in this research. There are relationships between teachers' competency on students' achievement. However insignificant effect has been found between parental involvements to students' achievement. Findings showed indirect effects of teachers' competency through students' motivation with students' achievement. However, the model had achieved the goodness of fit and supported the hypothesized model. It also has contributed as an additional literature on teacher competency in the context of Malaysian education. Further study should be conducted to improve the implementation of teacher competency especially related to parental involvement in order to increase the achievement among the vocational colleges.

\section{References}

Abd Razak, Z., Zuwati, H., \& Umi Kalsum, M. S. (2013). Family Context and its relationship with parental involvement in the education of secondary school chilren. International Journal of Asian Social Science, 3(4), 1063-1076.

Akiri, A. a. (2013). Effects of Teachers' Effectiveness on Students' Academic Performance in Public Secondary Schools; Delta State - Nigeria. Journal of Educational and Social Research, 3(3), 105-112.

Alkharusi, H., Aldhafri, S., Alnabhani, H., \& Alkalbani, M. (2014). Classroom Assesment: Teacher Practices, Student Perceptions, And Academic Sel-Eficacy Beliefs. Social Behavior and Personality, 42(5), 835-856.

Bartlett, J. E., Kotrlik, J. W., \& Higgins, C. C. (2001). Organizational Research: Determining Appropriate Sample Size in Survey Research. Information Technology, Learning, and Performance Journal, 19(1), 43-50.

Beamish, W., Meadows, D., \& Davies, M. (2012). Benchmarking Teacher Practice in Queensland Transition Programs for Youth With Intellectual Disability and Autism. The Journal of Special Education, 45(4), 227-241. 
Bentler, P. M. (2010). SEM with simplicity and accuracy. Journal of Consumer Psychology, 20(2), 215-220. doi:10.1016/j.jcps.2010.03.002

Byrne, B. M. (2010). Structural Equation Modeling with AMOS. Structural Equation Modeling (Vol. 22).

Cochran, W. F. (1977). Sampling techniques. (John Willey \& Sons, Ed.) (Third Edition.). United States of America: Harvard University.

Danielson, C. (2012). Observing Classroom Practice. Educational Leadership, 70(Number 3), 32-37.

Danielson, C. (2014). Teacher Evaluation and Development in the Common Core Era Where It All Began. In C. Danielso (Ed.), ASSD Annual Conference, March 16, 2014. Los Angeles, California: The Danielson Group.

Demircan, O., \& Erden, F. T. (2014). Parental Involvement and Developmentally Appropriate Practices: A Comparison of Parent and Teacher Beliefs. Early Child Development and Care, 185(2), 209-225.

Effendi, M. J. (2012). Faktor Yang Mempengaruhi Enrolmen Pelajar Aliran Pendidikan Teknik dan Vokasional. Universiti Tun Hussein Onn Malaysia. Tesis Sarjana.

Elliot, A. J., \& Church, M. A. (1997). A Hierarchical Model of Approach and Avoidance Achievement Motivation. Journal of Personality and Social Psychology, $72(1), 218-232$

Epstein, J. L. (1992). School and Partnerships. In Ecyclopedia of educational research. New York: Mac Millan.

Epstein, J. L., Mavis, G., Beth, S., Clark, K., Natalie, R., \& Frances, L. (2002). School, Family and Community Partnerships (Edition 2.). Corwin Press, Inc.

Furrer, C., \& Skinner, E. (2003). Sense of Relatedness as a Factor in Children's Academic Engagement and Performance. Journal of Educational Psychology.

Gefen, D., Straub, D. W., \& Boudreau, M.-C. (2000). Structural Equation Modeling and Regression: Guidelines for Research Practice. Communications of the Association for Information Systems, 4(October), 7.

Guvenc, H. (2015). The Relationship Between Teachers' Motivational Support and Engagement versus Disaffection. Journal of Educational Sciences: Theory and Practice, 15(3), 647-657.

Hair, Black, W. C., Babin, B. J., \& Anderson, R. E. (2010). Multivariate Data Analysis (Edition 7.). Pearson Prentice Hall Inc.

Hill, N. B., \& Tyson, D. F. (2009). Parental involvement in middle school: A meta-analytic assessment of the strategies that promote achievement. Developmental Psychology, 49, 740-763.

Hoover-Dempsey, K. V., Battiato, A. C., Walker, J. M. T., Reed, R. P., DeJong, J. M., \& Jones, K. P. (2001). Parental Involvement in Homework. Educational Psychologist, 36(3), 195-209.

Johnetta, W. M., Pamela, S., \& Chenyi, Z. (2011). Accessible Family Involvement in Early Childhood Programs. Dimensions of Early Childhood, $39(3), 21-26$.

Kline, R. B. (2011). Principles and Practice of Structural Equation Modelling (Edition 3.). New York: Guilford Press.

Lloyd-Smith, L., \& Baron, M. (2010). Beyond conferences: Attitudes of high school administrators toward parental involvement in one small midwestern state. School Community Journal, 20(2), 20-44.

Ministry of Education Malaysia. (2013). Malaysia Education Blue Prints (2013-2025). Education Performance and Delivery Unit (PADU).

Mohd Effendi Ewan, M. M., Ahmad Zamri, K., \& Nordin, A. R. (2015). The Influence of AQ on the Academic Achievement among Malaysian Polytechnic Students. International Educational Studies, 8(6), 69-74

Murray, E., McFarland-Piazza, L., \& Harrison, L. J. (2015). Changing Patterns of Parent-Teacher Communication and Parent Involvement From Preschool to School. Early Child Development and Care, 185(7), 1031-1052.

Nor Aniza, A., Siti Aishah, H., Lay Nee, C., \& Nor Hashim, O. (2016). The Typlogy of Parental Engagement and its Relationship with the Typlogy of Teaching Practices, Motivation Achievement, Self-Concept and Academic Achievement. Journal of Management and Marketing Review, 1(1).

Nurazimah, B., \& Yusri, K. (2013). Implikasi Penjenamaan Semula Sekolah Menengah Vokasional (SMV) Kepada Kolej Vokasional (KV). In 2nd International Seminar on Quality and Affordable Education (ISQAE 2013) (pp. 316-323). Johor Bharu, Malaysia: Fakulti Pendidikan, UTM.

Onete, O. U., \& Calabar, C. (2012). Academic Performance: A Function of Achievement Motivation Among Education Students of Cross River University of Technology , Calabar. Journal of Review of Higher Education in Africa, 4(ISSN 1916-7881), 63-83.

Programme for International Student Assessment. (2014). PISA 2012 Results in Focus: What 15 years old know and what they van do with what they know. Turkey.

Rachel, C. R., \& Sean, J. S. (2014). Understanding the Roles of Families in Virtual Learning. Teaching Exceptional Children, 46(5), 117-126.

Ramlee, M., \& Abu, A. (2014). Malaysia Transitions Toward a Knowledge-Based Economy. The Journal of Tecnologies Study, 51-61.

Reece, C. A., Staudt, M., \& Ogle, A. (2013). Lessons Learned From a Neighborhood-Based Collaboration to Increase Parent Engagement. School Community Journal, 23(2), 207-226.

Reeves, C. R. (1993). Using Genetic Algorithms With Small Populations. Proceedings of the 5th International Conference on Genetic Algorithms, 92-99.

Siti Syahirah, A. Z. (2011). Transformasi PTV:Kesediaan Guru-guru Vokasional terhadap Pelaksanaan Sekolah Vokasional KPM dari Aspek Tahap Kemahiran. In Persidangan Kebangsaan Penyelidikan Dan Inovasi Dalam Pendidikan Dan Latihan Teknik Dan Vokasional (CIETVT 2011) (pp. 101-115). Batu Pahat, Johor: CIETVT, Universiti Tun Hussein Onn, Malaysia.

Trung Lam, B., \& Ducreux, E. (2013). Parental Influence and AcademicAchievement among Middle School Students: Parent Perspective. Journal of Human Behavior in the Social Environment, 23(5), 550-579.

Vallerand, R. J. (1992). The Academic Motivation Scale : A Measure Of Intrinsic, Extrinsic And Amotivation In Education.

Zainudin, A. (2015). SEM Made Simple. A Gentle Approach to Learning Structural Equation Modeling (Edition 1.). Bandar Baru Bangi, Selangor, Malaysia.: MPWS, Rich Publication.

Zakharov, A., Carnoy, M., \& Loyalka, P. (2014). Which Teaching Practices Improve Student Performance on High Stakes Exams? Evidence from Russia. International Journal of Educational Development, 36, 13-21. 